\title{
ACETABULUM: A MORPHOMETRIC STUDY
}

Gursharan Singh Dhindsa

\section{Assistant Professor, Department of Anatomy, Guru Gobind Singh Medical College, Faridkot, Punjab.}

\section{CORRESPONDING AUTHOR}

Dr. Gursharan Singh Dhindsa,

Assistant Professor,

Department of Anatomy,

Guru Gobind Singh Medical College,

Sadiq Road, Faridkot, Punjab,

E-mail: gursharan91@rediffmail.com

Ph: 00919417979939

ABSTRACT: AIM: A morphometric study of acetabulum of 50 dry human hip bones in Ludhiana, Punjab was done to evaluate the various parameters of acetabulum. MATERIAL AND METHODS: 50 human adult unpaired dry hip bones (25 right and 25 left) of unknown sex were collected in the Department of Anatomy, Dyanand Medical College, Ludhiana, Punjab to analyze and evaluate the depth, diameter and capacity of acetabulum. RESULTS: The raw data obtained was statistically analyzed. Range, mean, standard deviation and standard error of mean were determined for each parameter. All values were compared with series of other workers to draw the conclusions. CONCLUSIONS: All the parameters showed a greater value for the right side. The capacity of acetabulum showed dependence on its diameter. With an increase in diameter there was an increase in capacity of the acetabulum. A sound knowledge of various parameters of the acetabulum is important for the forensic experts, anthropologists and anatomists.

KEY WORDS: acetabulum, hip joint, morphometry, prosthesis, arthoplasty

INTRODUCTION: The acetabulum is an approximately hemispherical cavity surrounded by an irregular margin deficient inferiorly at the acetabular notch. It is composed of a rough nonarticular part called the acetabular fossa and a smooth lunate articular surface. All three innominate elements (ilium, ischium and pubis) contribute to the acetabulum in man but unequally. The pubis forms the antero superior fifth of the articular surface, the ischium forms the fossa's floor and more than the postero inferior two-fifths of the articular surface, and the ilium the remainder.[1]

The hip joint is one of the major weight bearing joints of the body. The knowledge of normal anatomical features and morphometry of the acetabulum are prerequisites for complete understanding of the mechanics of hip joint. This information acts as a basis for the making of hip joint prosthesis.

An incongruous joint is more prone to develop degenerative changes than a joint having normal anatomy.[2] A bigger roof of the acetabular cup means a good grip of the head of the femur inside the acetabulum and hence a better result of arthoplasty.[3] Therefore, the knowledge on hip bone would be complete if the dimensions of acetabulum are also incorporated. The relative preponderance of the articular area in relation to non-articular area would indicate better adaptation and firmer grip of the head of the femur inside the acetabular socket. In the converse condition, the 'grasp' for the head of the femur might be weaker to produce a comparatively less stable hip joint.[4] 
The size, shape and depth of the acetabulum are variable as reported by Govsa F et al.[5] Therefore, the knowledge of various parameters of acetabulum would be helpful in performing surgical procedures such as acetabular reconstruction and planning reorientation procedures using spikes and screws for fixation.

Racial differences in Thais, Chinese, Nigerians and other populations have been compared.[6,7] Inspite of this not much work has been done in Indian population. Therefore present study was carried out in Ludhiana, Punjab which provides valuable parameters which would help the forensic experts, anthropologists, orthopaedicians and prosthetists.

\section{OBJECTIVE:}

To study morphometry of the acetabulum in 50 adult dry human hip bones (25 right \& 25 left) in Ludhiana, Panjabi population to:

Evaluate various parameters of acetabulum.

MATERIAL AND METHODS: A total of 50 Ludhiana, Panjabi adult unpaired right and left dry hip bones of unknown sex were studied from teaching collection of the Anatomy department. Out of the total of 50 hip bones, 25 were of right side and 25 were of left side. All the hip bones selected were dry, complete and showed normal anatomical features. Specimens showing osteoarthritic changes, evidence of any previous trauma or skeletal disorders was excluded from the study.

All the measurements were taken with the help of vernier caliper, measuring cylinder and plasticine. Three readings were taken for each parameter at different times and the average was recorded. Range, mean, standard deviation and standard error of mean were determined for each parameter. All values were compared with series of other workers to draw the conclusions.

1. DIAMETER OF ACETABULUM: It is described as the maximum transverse distance between the margins of the acetabular cavity. It was measured using a vernier caliper and the readings were noted in centimeters.

2. DEPTH OF ACETABULUM: It is described as the maximum vertical distance from the brim of the acetabulum to the deepest point in the acetabular cavity. It was measured using a vernier caliper. It can be measured by using a thin metallic strip placed across the brim of the acetabular cavity and then the distance from the metallic strip to the deepest point in the acetabulum using a vernier caliper. The readings were noted in centimeters.

3. CAPACITY OF ACETABULAR CAVITY: It is described as the volume of the cavity of the acetabulum. The acetabular cavity was filled with plasticine up to its brim (Fig.3) and then it was transferred to a water filled graduated measuring cylinder (Fig.4). The volume of water displaced gave the capacity of the acetabular cavity.

DISCUSSION: The study would be of help the forensic experts in specimen identification and sex determination from skeleton remains. It would also be valuable for the anthropologists in their racial and population studies.

Many workers have studied the diameter of acetabulum. In the present study, mean diameter of acetabulum is $5.13 \mathrm{~cm}$ on right side and $5.03 \mathrm{~cm}$ on left side. As it can be seen in the table no.7 values noted by most of the authors are consistent with present study values. The values noted by Lander ${ }^{[9]}$ and Rosenberg KR et al [17] are higher than the present study values. 
The mean depth of acetabulum in present study is $2.67 \mathrm{~cm}$ on right side and $2.64 \mathrm{~cm}$ on left side. The values are consistent with values noted by Mukhopadhaya and Barooah [10], Luna [12] and Chauhan et al [14]. The reading of Salamon et al [15] is higher than the present study readings, which may probably be due to racial variations. The values noted by Genser- Strobl and Sora [16] are lower than the present study values because of difference in method used in measurement. Many authors like Croft et al [18], Lau et al [19], Smith et al [20], Lane et al [21] and Lequesne et al [22] studied the depth of acetabulum on radiographs. As a result their studies show much lower values as compared to present study values.

The capacity of acetabulum in present study is $36.68 \mathrm{ml}$ on right side and $33.56 \mathrm{ml}$ on left side. In a study done by Taher [4] the values were quite low as compared to present study. The lower values may probably be due to the regional variations.

All parameters showed a higher value for the right side as compared to the left side. The most striking difference between the right and left side values was seen in case of the capacity of the acetabulum. These parameters are at a variance from the past researchers. One of the probable reasons could be that the hip bones we measured were taken at random, i.e. the right and left sided bones were not from the same skeleton. Hence, ideally the measurements of the two sides should be taken from bones belonging to the same skeleton.

Manual method can be done only in dry bones, whereas it is only the radiological method that is followed in living. Therefore the readings obtained by manual method are more accurate than those obtained by the radiological method. Thus it would be of help to the prosthesits in modeling the prosthesis, as the readings are near the real value.

\section{CONCULSIONS:}

1. Mean diameter of acetabulum was $5.13 \pm 0.26 \mathrm{~cm}$ on the right side and $5.03 \pm 0.35$ $\mathrm{cm}$ on the left side. The total range for diameter of acetabulum was $4.2-5.6 \mathrm{~cm}$ ( $62 \%$ hip bones had diameter of acetabulum between $5-5.4 \mathrm{~cm}$ ).

2. Mean depth of acetabulum was $2.67 \pm 0.27 \mathrm{~cm}$ on the right side and $2.64 \pm 0.30 \mathrm{~cm}$ on the left side. The total range for depth of acetabulum was $2.0-3.2 \mathrm{~cm}(58 \%$ hip bones had depth of acetabulum between $2.5-2.9 \mathrm{~cm}$ ).

3. Mean capacity of acetabulum was $36.68 \pm 6.23 \mathrm{ml}$ on the right side and $33.56 \pm 5.63$ $\mathrm{ml}$ on the left side. The total range for capacity of acetabulum was $20-55 \mathrm{ml}(68 \%$ hip bones had capacity of acetabulum between $30-39.9 \mathrm{ml}$ ).

In the present study it was observed that there was an overall greater robusticity of acetabulum of right hip bone.

The capacity of acetabulum showed dependence on its diameter. With an increase in diameter there was an increase in capacity of the acetabulum.

The difference seen between the values of present study and that of other workers could be explained on the basis of ethnic and racial variations.

However it should be kept in mind, that the present study had a smaller number of hip bones and were not of the same skeleton, it is difficult to conclude these readings as standard ,in any practical appliances. So it is worthwhile to perform similar study on more number of hip bones for its theoretical and practical importance in the coming years.

\section{REFERENCES:}


1. Soames RW. Skeletal System. In: Williams PL, Bannister LH, Berry MM, Collins P, Dyson M, Dussek JE, et al, editors. Gray's Anatomy, The Anatomical Basis of Medicine and Surgery. 38 ${ }^{\text {th }}$ ed. Churchill Livingstone; 1995. p. 425-736.

2. Murray RO. The aetiology of primary osteoarthritis of the hip. Br J Radiol 1965; 38: 81024.

3. Denham RA, Alexander LW. Arthroplasty of the hip. J Bone Joint Surg 1957; 39 B: 61422.

4. Taher SA. Surface area of the acetabular cavity in contour and its capacity in man and in great apes. J Anat Soc India 1969; 18: 84-90.

5. Govsa F, Ozer MA, Ozgur Z. Morphological features of the acetabulum. Arch Orthop Trauma Surg 2005; 125: 453-61.

6. Varodompun N, Thinley T, Visutipol B, Ketmalasiri B, Pattarabunjerd N. Correlation between the acetabular diameter and thickness in Thais. J Orthop Surg (Hong Kong) 2002; 10: 41-4.

7. Msamati BC, Igbigbi PS, Lavy CB. Geometric measurements of the acetabulum in adult Malawians: radiographic study. East Afr Med J 2003; 80: 546-9.

8. Derry DE. Note on the innominate bone as a factor in the determination of sex: with special reference to the sulcus preauricularis. J Anat Physiol 1909; 43: 266-76.

9. Lander KF. The examination of a skeleton of known age, race, and sex. J Anat 1918; 52: 282-91.

10. Mukhopadhaya B, Barooah B. Osteoarthritis of hip in Indians: an anatomical and clinical study. Indian J Orthop 1967; 1: 55-62.

11. Wu X, Shao X, Wang H. Sex differences and sex determination of the innominate bone of modern Han nationality. Acta Anat Sin 1982; 1: 118-31.

12. Luna MP, Desnoyers V, Charissoux JL, Mavit C, Arnaud JP. Morfological study of the human acetabulum: Biometry. Rev Chil Anat 1998; 16: 5-7.

13. Rosenberg K. A late Pleistocene human skeleton from Liujiang, China suggests regional population variation in sexual dimorphism in the human pelvis. Variabilty and Evolution 2002; 10: 5-17.

14. Chauhan R, Paul S, Dhaon BK. Anatomical parameters of North Indian hip jointscadaveric study. J Anat Soc India 2002; 51: 39-42.

15. Salamon A, Salamon T, Sef D, Jo-Osvatic A. Morphological characteristics of the acetabulum. Coll Anthropol 2004; 28 Suppl 2: 221-6.

16. Genser- Strobl B, Sora MC. Potential of P40 Plastination for morphometric hip measurements. Surg Radiol Anat 2005; 27: 147-51.

17. Rosenberg KR, Zune L, Ruff CB. Body size, body proportions and encephalization in a middle Pleistocene archaic human from Northern China. Proc Natl Acad Sci USA 2006; 103: 3552-6.

18. Croft P, Cooper C, Wickham C, Coggon D. Osteoarthritis of the hip and acetabular dysplasia. Ann Rheum Dis 1991; 50: 308-10.

19. Lau EMC, Lin F, Lam D, Silman A, Croft P. Hip osteoarthritis and dysplasia in Chinese men. Ann Rheum Dis 1995; 54: 965-9.

20. Smith RW, Egger P, Coggon D, Cawley MID, Cooper C. Osteoarthritis of the hip joint and acetabular dysplasia in women. Ann Rheum Dis 1995; 54: 179-81.

21. Lane NE, Nevitt MC, Cooper C, Pressman A, Gore R, Hochberg M. Acetabular dysplasia and osteoarthritis of the hip in elderly White women. Ann Rheum Dis 1997; 56: 627-30. 
22. Lequesne M, Malghem J, Dion E. The normal hip joint space: variations in width, shape and architecture on 223 pelvic radiographs. Ann Rheum Dis 2004; 63: 1145-51.

\section{RESULTS:}

Table1: Showing Comparison of Diameter of Acetabulum of Hip Bone (in cm)

\begin{tabular}{|l|l|l|l|l|}
\hline Side & Mean & Standard Deviation & Standard Error of Mean & Range \\
\hline Right & 5.13 & 0.26 & 0.05 & $4.7-5.6$ \\
\hline Left & 5.03 & 0.35 & 0.07 & $4.2-5.6$ \\
\hline Total & $\mathbf{5 . 0 8}$ & $\mathbf{0 . 3 1}$ & $\mathbf{0 . 0 6}$ & $\mathbf{4 . 2 - 5 . 6}$ \\
\hline
\end{tabular}

Table 2: Showing Distribution of Diameter of Acetabulum of Hip Bone

\begin{tabular}{|l|l|l|l|l|}
\hline $\begin{array}{l}\text { Diameter of } \\
\text { acetabulum } \\
\text { (in cm) }\end{array}$ & $\begin{array}{l}\text { No. of Right Hip } \\
\text { Bones }\end{array}$ & Percentage & $\begin{array}{l}\text { No. of Left Hip } \\
\text { Bones }\end{array}$ & Percentage \\
\hline $4-4.4$ & 0 & 0 & 2 & 8 \\
\hline $4.5-4.9$ & 6 & 24 & 6 & 24 \\
\hline $5-5.4$ & 15 & 60 & 16 & 64 \\
\hline $5.5-5.9$ & 4 & 16 & 1 & 4 \\
\hline
\end{tabular}

Table 3: Showing Comparison of Depth of Acetabulum of Hip Bone (in cm)

\begin{tabular}{|l|l|l|l|l|}
\hline Side & Mean & Standard Deviation & Standard Error of Mean & Range \\
\hline Right & 2.67 & 0.27 & 0.05 & $2.3-3.2$ \\
\hline Left & 2.64 & 0.30 & 0.06 & $2.0-3.2$ \\
\hline Total & $\mathbf{2 . 6 6}$ & $\mathbf{0 . 2 9}$ & $\mathbf{0 . 0 5}$ & $\mathbf{2 . 0 - 3 . 2}$ \\
\hline
\end{tabular}

Table 4: Showing Distribution of Depth of Acetabulum of Hip Bone

\begin{tabular}{|l|l|l|l|l|}
\hline $\begin{array}{l}\text { Depth of Acetabulum } \\
\text { (in cm) }\end{array}$ & $\begin{array}{l}\text { No. of Right Hip } \\
\text { Bones }\end{array}$ & Percentage & $\begin{array}{l}\text { No. of Left Hip } \\
\text { Bones }\end{array}$ & Percentage \\
\hline $2-2.4$ & 7 & 28 & 6 & 24 \\
\hline $2.5-2.9$ & 14 & 56 & 15 & 60 \\
\hline $3-3.4$ & 4 & 16 & 4 & 16 \\
\hline
\end{tabular}


Table5: Showing Comparison of Capacity of Acetabulum of Hip Bone (in ml)

\begin{tabular}{|l|l|l|l|l|}
\hline Side & Mean & Standard Deviation & Standard Error of Mean & Range \\
\hline Right & 36.68 & 6.23 & 1.27 & $25-55$ \\
\hline Left & 33.56 & 5.63 & 1.15 & $20-45$ \\
\hline Total & $\mathbf{3 5 . 1 2}$ & $\mathbf{5 . 9 3}$ & $\mathbf{1 . 2 1}$ & $\mathbf{2 0 - 5 5}$ \\
\hline
\end{tabular}

Table 6: Showing Distribution of Capacity of Acetabulum of Hip Bone

\begin{tabular}{|l|l|l|l|l|}
\hline $\begin{array}{r}\text { Capacity of } \\
\text { Acetabulum (in ml) }\end{array}$ & $\begin{array}{l}\text { No. of Right Hip } \\
\text { Bones }\end{array}$ & Percentage & $\begin{array}{l}\text { No. of Left Hip } \\
\text { Bones }\end{array}$ & Percentage \\
\hline $20-29.9$ & 1 & 4 & 3 & 12 \\
\hline $30-39.9$ & 16 & 64 & 18 & 72 \\
\hline $40-49.9$ & 7 & 28 & 4 & 16 \\
\hline $50-59.9$ & 1 & 4 & 0 & 0 \\
\hline
\end{tabular}

Table 7: Comparison of Diameter of Acetabulum in Present study and previous studies.

\begin{tabular}{|l|l|l|l|}
\hline \multirow{2}{*}{ Author } & \multicolumn{3}{|l|}{ Diameter of Acetabulum (cm) } \\
\cline { 2 - 4 } & Male & Female & \multicolumn{1}{l|}{$\begin{array}{l}\text { Unknown } \\
\text { sex }\end{array}$} \\
\hline Derry DE[8] & 5.20 & 4.68 & \\
\hline Lander KF[9] & & & $\begin{array}{l}5.70(\mathrm{Rt} .) \\
\text { 5.60(Lt.) }\end{array}$ \\
\hline Mukhopadhaya B \& Barooah B[10] & & & $4.57(\mathrm{Rt})$. \\
& & & $4.59(\mathrm{Lt})$. \\
\hline Wu X et al[11] & 5.53 & 4.96 & \\
\hline Luna MP et al[12] & & & 4.95 \\
\hline Rosenberg K[13] & & & $4.72(\mathrm{Rt})$. \\
\hline Varodompun N et al[6] & & & 5.18 \\
\hline Chauhan R et al[14] & $4.71(\mathrm{Rt})$. & $4.44(\mathrm{Rt})$. & \\
\hline Salamon A et al[15] & $4.75(\mathrm{Lt})$. & $4.60(\mathrm{Lt})$. & \\
\hline Genser-Strobl B \& & & & 5.16 \\
\hline Sora MC[16] & & & 4.89 \\
\hline Rosenberg KR et al[17] & & & \\
\hline Present Study & & & 5.93 \\
\hline
\end{tabular}


Table 8: Comparison of Depth of Acetabulum in Present study and previous studies.

\begin{tabular}{|l|l|l|l|}
\hline \multirow{2}{*}{ Author } & \multicolumn{3}{|l|}{ Depth of Acetabulum (cm) } \\
\cline { 2 - 4 } & Male & Female & Unknown sex \\
\hline $\begin{array}{l}\text { Mukhopadhaya B \& } \\
\text { Barooah B[10] }\end{array}$ & & & $\begin{array}{l}2.47(\mathrm{Rt} .) \\
2.45(\mathrm{Lt} .)\end{array}$ \\
\hline $\begin{array}{l}\text { Croft P et al[18] } \\
\text { (on radiographs) }\end{array}$ & & & 1.44 \\
\hline $\begin{array}{l}\text { Lau EMC et al[19] } \\
\text { (on radiographs) }\end{array}$ & & & 1.18 \\
\hline $\begin{array}{l}\text { Smith RW et al [20] } \\
\text { (on radiographs) }\end{array}$ & & & 1.44 \\
\hline $\begin{array}{l}\text { Lane NE et al[21] } \\
\text { (on radiographs) }\end{array}$ & & & $1.19(\mathrm{Rt})$. \\
\hline Luna MP et al[12] & & & $1.22(\mathrm{Lt})$. \\
\hline Chauhan R et al[14] & $2.75(\mathrm{Rt})$. & $2.47(\mathrm{Rt})$. & \\
\hline $\begin{array}{l}\text { Lequesne M et al[22] } \\
\text { (on radiographs) }\end{array}$ & $2.82(\mathrm{Lt})$. & $2.57(\mathrm{Lt})$. & \\
\hline Salamon A et al[15] & & & 1.16 \\
\hline $\begin{array}{l}\text { Genser-Strobl B \& } \\
\text { Sora MC[16] }\end{array}$ & & & 3.0 \\
\hline Present Study & & & 1.64 \\
\hline
\end{tabular}

Table 9: Comparison of Capacity of Acetabulum in Present study and previous studies.

\begin{tabular}{|l|l|l|l|}
\hline \multirow{2}{*}{ Author } & \multicolumn{3}{|l|}{ Capacity of Acetabulum (ml) } \\
\cline { 2 - 4 } & Male & Female & Unknown sex \\
\hline Taher SA[4] & 28 & 21.50 & \\
& & & $36.68(\mathrm{Rt})$. \\
Present Study & & & $33.56(\mathrm{Lt})$. \\
\hline
\end{tabular}




\section{ORIGINAL ARTICLE}

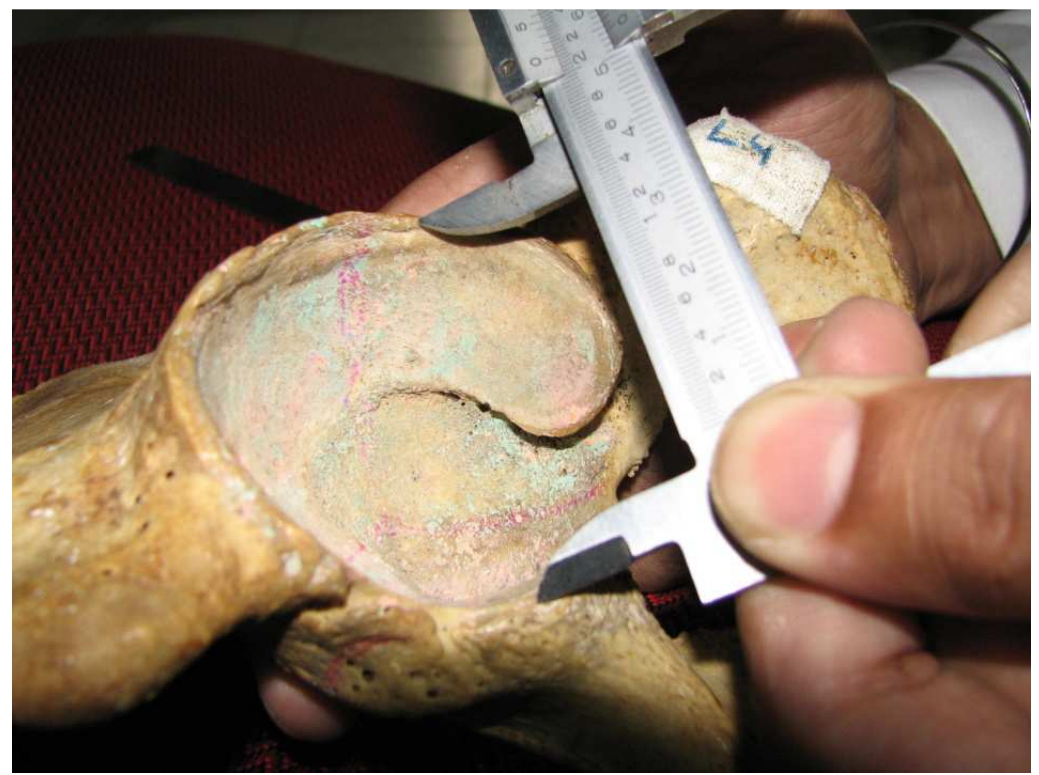

Fig 1: Photograph showing measurement of diameter of acetabulum using vernier caliper.

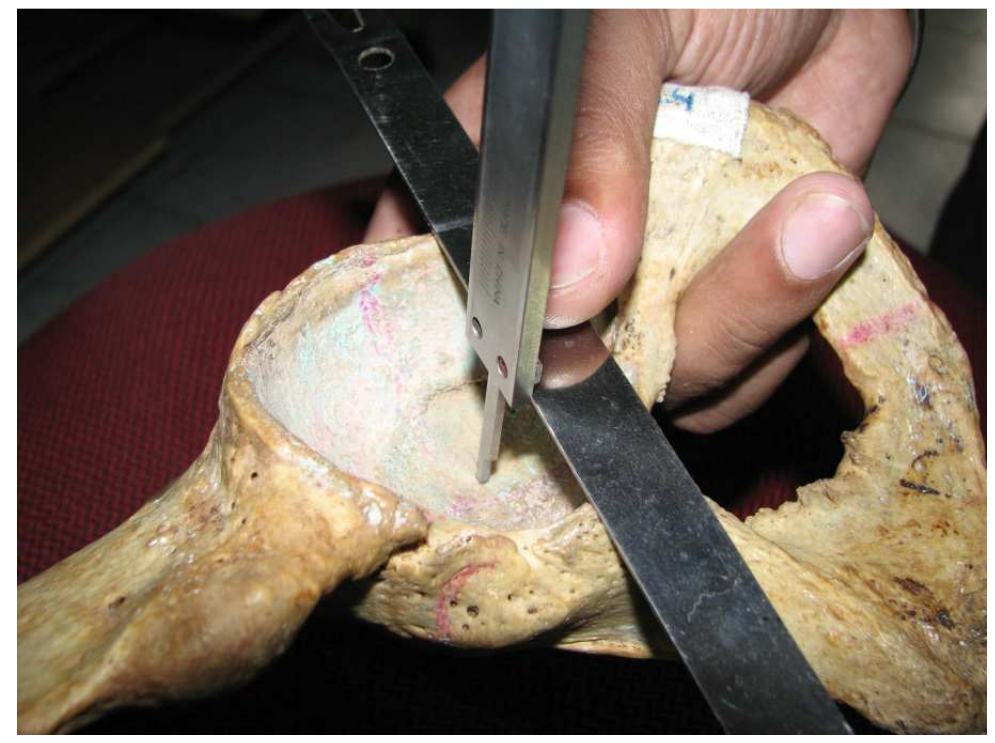

Fig 2: Photograph showing measurement of depth of acetabulum using vernier caliper. 


\section{ORIGINAL ARTICLE}

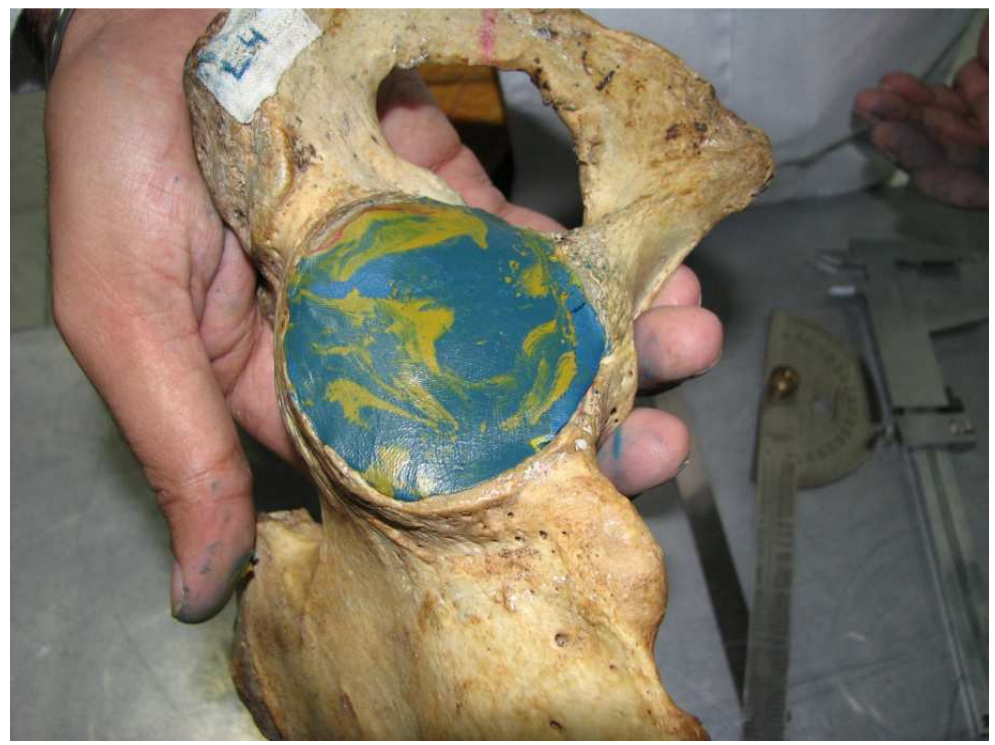

Fig. 3: Photograph showing acetabular cavity filled with plasticine up to its brim.

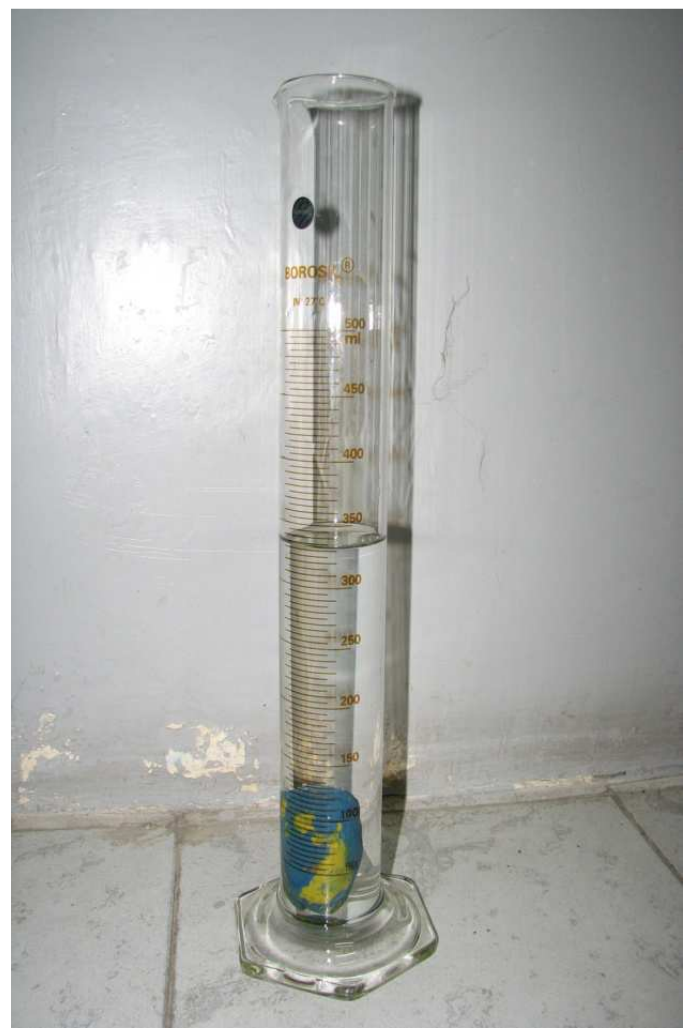

Fig.4: Photograph showing measurement of capacity of acetabular cavity using a measuring cylinder. 